\title{
Pharmacognostical, Phytochemical and Nutritional Evaluation of Glinus oppositifolius (L.) Aug. DC.
}

\author{
Shantha Thirumalai Ramaseshan ${ }^{1 *}$, Patchaimal Pitchaiah' ${ }^{1}$, Prathapa Reddy Maramreddy', Vandana Bharti ${ }^{1}$, Kishore Kumar Ramakrishna', \\ Venkateshwarlu Gaddam', Devesh Tewari², Chinmay Rath², Anupam Kumar Mangal2 ${ }^{2}$ Padhi Madan Mohan² and Dhiman Kartar Singh² \\ 'National Ayurveda Dietetics Research Institute, Central Council for Research in Ayurvedic Sciences, Ashoka pillar, Jayanagar, Bangalore-560011, India. \\ ${ }^{2}$ Central Council for Research in Ayurvedic Sciences, Ministry of AYUSH, Government of India, Janakpuri, New Delhi-110058, India.
}

\begin{abstract}
Objective: The primary aim of the study was to establish the pharmacognostic standards along with nutritional values on the important medicinal herb Glinus oppositifolius (L.) Aug. DC., commonly known as Parpata in South India. Material and Methods: Pharmacognostical, physicochemical, nutritional evaluation along with the TLC profiling and preliminary phytochemical screening was carried out. Results: Histological study of different parts of the plant revealed the presence of different cellular structures viz. stem showed the presence of multi cellular to unicellular trichomes, collateral vascular bundles, starch grains etc. Mesophyll of the leaves was embedded with starch grains with clustered calcium oxalate and prism shaped crystals. Anomocytic stomata were present on both the epidermis of the leaf. Powder microscopy exhibited multi cellular trichomes, clustered calcium oxalate, fibres etc. Physicochemical and histochemical studies revealed the presence of various secondary metabolites and different minerals within the acceptable limits. Thin layer chromatographic profiling showed different spots suggesting the presence of specific phytoconstituents in different extracts. The plant also revealed good nutritional value with calorific value of about $245 \mathrm{kcal} / 100 \mathrm{~g}$; Vitamin C $112 \mathrm{mg} / 100 \mathrm{~g}$ and higher amount of
\end{abstract}

calcium etc. Conclusion: The results are beneficial to establish the quality control parameters of the plant species and may be served as future reference for the identification and authentication of the genuine crude drug and also provide sufficient data to recognize the use of the plant as dietary suppliment.

Key words: Antidiabetic, Pharmacognosy, Standardization, Thin layer chromatography, Powder microscopy, Histochemical studies.

\section{Address for Correspondence:}

Dr. Shantha Thirumalai Ramaseshan, Drug Standardization Research Unit, Research Officer (Botany), National Ayurveda Dietetics Research Institute, (CCRAS, Ministry of AYUSH, Govt. of India), Bangalore-560011, India.

Phone no: 91- 9986365762, Telephone (O): 91-080-26562030

E-mail: shanthatr57@gmail.com

DOI : 10.5530/pj.2016.1.7

\section{INTRODUCTION}

Standardization of crude drugs is still a challenge in the research and development of herbal preparations. There are several standardization procedures available for the proper identification and authentication of the medicinal plants, among these identification parameters the pharmacognostical study is accepted method for the quality control analysis of the crude drugs.

In Ayurveda many plants are used in the name of Parpata viz. Oldenlandia corymbosa L., Polycarpaea corymbosa Lam., Justicia procumbens L., Rungia repens (L.) Nees., Peristrophe bicalyculata (Retz.) Nees., Glossocardia linearifolia Cass., Mollugo oppositifolia L., Fumaria officinalis L., Fumaria parviflora Lam., Scoparia dulcis L. and Mollugo stricta L. ${ }^{1,2}$ for the cure of various ailments. However, official drug in the name of Parpata is Fumaria parviflora Lam. ${ }^{3}$ and all remaining plants which are in the name of Parpata can be referred as Parpata Bheda or substitutes/ alternate. Among these one of the important medicinal plant is Glinus oppositifolius (L.) Aug. DC. [Mollugo oppositifolia L.; Mollugo spergula (L.)] belonging to the family of Molluginaceae; is a common diffuse, prostrate or ascending annual herb; numerous branched stems up to 2 feet long and a stout taproot, distributed in greater part of India, particularly in Assam, Deccan peninsula and West Bengal. Leaves falsely whorled, oblong-obovate or spathulate, sometimes thinly hairy; flowers white or greenish in axillary fascicles; capsules 3-4 valved, containing many reniform strophiolate seeds. ${ }^{4}$
The plant has immense therapeutic potential; it is a potential source of natural antioxidant, ${ }^{5,6}$ leaves showed anthelmintic and antioxidant activity, ${ }^{7}$ hepatoprotective activity, ${ }^{8-10}$ analgesic, anti-inflammatory activity ${ }^{11}$ and antihyperglycemic activity. ${ }^{12,13}$ The plant is also used in the ethno medical practices. One of the important uses of the plant is as a tonic to postpartum mothers ${ }^{14}$ reported by Narikorava tribe of Tamil Nadu; it is also useful as a bitter tonic for liver disorders. ${ }^{15}$ It is used as stomachic and antiseptic; the plant is administered for suppression of the lochia and when applied warm and moistened with a little castor oil; is reckoned a good application for earache and the juice is applied for dermatitis/ pruritis and other skin diseases. ${ }^{16}$ The plant extract is used as stomachic, carminative and for tonic purpose by the tribes of Nandurbar district of Maharashtra (India). ${ }^{17}$ Its leaves are used in the forest tract of Salem region of Tamil Nadu, India for animal bite poison by local healers. ${ }^{18}$ The diverse medicinal properties of the plant and very less pharmacognostical studies, prompted the authors to further investigate the plant for establishment of pharmacognostical standards with chromatographic analyses. The study has been carried out to evaluate the diagnostic features of different organs of the Glinus oppositifolius (L.) Aug. DC. which is useful as antidiabetic medicine in addition to parts used as vegetable. The plant is also utilized as a common dietary principle mainly in South India therefore an attempt has been made to quantify the nutritional values of the plant for the value addition. 


\section{MATERIALS AND METHODS}

\section{Procurement of plant material}

Whole plant of the Glinus oppositifolius (L.) Aug. DC. was collected from Mukkellapadu village, Krishna district, Andhra Pradesh and K. R. Puram Market, Bangalore; identified by Taxonomist from Survey of Medicinal Plant Unit, National Ayurveda Dietetics Research Institute, Bangalore. The herbarium specimen was deposited in RRCBI Herbarium, Bangalore with Voucher Specimen no. 12358 for future reference. The plant material was shade dried, powdered and preserved in airtight container.

\section{Pharmacognostic Study}

\section{Macroscopy}

Macroscopic characters were evaluated according to the standard protocols..$^{19,20}$

\section{Microscopy}

Various plant organisms were soaked in $70 \%$ alcohol followed by free hand sections as per standard prescribed methods. Powder drug analysis and quantitative microscopical studies were carried out. ${ }^{19,20}$

\section{Histochemical study}

Histochemical evaluation provides an initial knowledge about the presence of various group of phytochemical in the cellular and histological structures of the plants. The tests were carried out for different parts with fresh samples. ${ }^{21}$

\section{Physico-Chemical analysis}

Physicochemical analysis viz. total ash, acid insoluble ash, $\mathrm{pH}$ of $5 \%$ aqueous solution, water, alcohol soluble extractives were carried out as per the standard procedure ${ }^{22}$ along with the petroleum ether and chloroform soluble extractive values by soxhlet extraction was done.

\section{Preliminary phytochemical screening}

Preliminary phytochemical screening for secondary metabolites like alkaloids, carbohydrates, proteins, terpenoides, steroids, tannins, phenols, starch etc. were carried out for different extracts as per the standard procedures. ${ }^{23}$

\section{Thin Layer Chromatography (TLC)}

TLC studies of these extracts were carried out by precoated Silica gel 60 $\mathrm{F}_{254}$ plates (Merck, Germany) which posses standardized adsorption layers, at room temperature. All the solvents systems were selected by trial and error basis. The chromatograms were developed in twin through glass chambers on $(10 \times 10 \mathrm{~cm})$ plates till the mobile phase travelled up to a distance of $8 \mathrm{~cm}$ from starting point. After development the plates were dried at room temperature for 5-10 minutes and observed under UV254 and UV-356 wavelength and $\mathrm{R}_{\mathrm{f}}$ values were recorded. All the plates were sprayed with $10 \% \mathrm{H}_{2} \mathrm{SO}_{4}$ and anisaldehyde- $\mathrm{H}_{2} \mathrm{SO}_{4}$ spraying reagent, dried at $105^{\circ} \mathrm{C}$ in hot air oven, before the observations of the $\mathrm{R}_{\mathrm{f}}$ values. ${ }^{24}$

\section{Nutritional evaluation}

The drug was shade dried, powdered and Nutritional analysis carried out on selected parameters like Proteins, carbohydrates, Vitamin C, calcium, Iron, zinc, vitamin B1, B2, B3, fat, calories, crude fibre, moisture, minerals etc. using standard protocols as mentioned in AOAC guideline. ${ }^{25}$

\section{RESULT AND DISCUSSION}

\section{Macroscopical characters}

The macromorphological evaluation of the plant showed the presence of numerous stem, dichotomously branched with long internodes, slender, glabrous or pubescent near the ends. Stem greenish yellow, compressed, fibrous, easy to break by hand, surface rough, round. Leaves are whorls, 4-5, unequal, oblanceolate or linear lanceolate or sometimes spathulate, rounded or acute and apiculate at apex, much tapered into the petiole which is therefore obscure. Petiole $0.5-0.8 \mathrm{~mm}$ long, leaves smaller in size, up to $1 \mathrm{~cm}$ long, green in colour, with unpleasant odour and bitter taste. Flowers white, in axillary fasciles of 2 or more, pedicel $6-13 \mathrm{~mm}$, long, filiform. Calyx glabrous outside, sepals $4 \mathrm{~mm}$, long, oblong, subacute with membranous margins, staminodes; stamens usually three. Ovary glabrous, style 3, very short, stigma spreading. Capsules ellipsoid, a little shorter than the sepals, 3 celled. Presence of numerous seeds, subreniform, with raised tubercular points, dark brown, appendage with a very small white scale at the hilum extened into a bristle which curves round the seed.

\section{Microscopical characters of stem}

Transverse section of stem showed a single layer of epidermis made up of loosely arranged rectangular shaped parenchyma cells covered by a thin layer of cuticle, where some of the epidermal cells were elongated to form multi cellular trichomes arranged in distant manner followed by epidermis region, 4 to 6 layers of compactly arranged thin walled parenchymatous cells filled with abundant starch grains with rosette type of calcium oxalate crystals at the cortex region was found followed by the cortex 2-3 layers of compactly arranged lignified sclerenchymatous layer of cells were present. Beside the sclerenchymatous layer, vascular bundles were present, where vascular bundles were collateral, conjoint, closed and meta xylem cells are facing towards the sclerenchymatous region and proto xylem cells facing towards the pith region. In the centre portion, pith region is made up of many layers of cells, where parenchymatous cells are thin walled, compactly arranged and a few cells showed small starch grains and crystals of calcium oxalate (Figure 1).
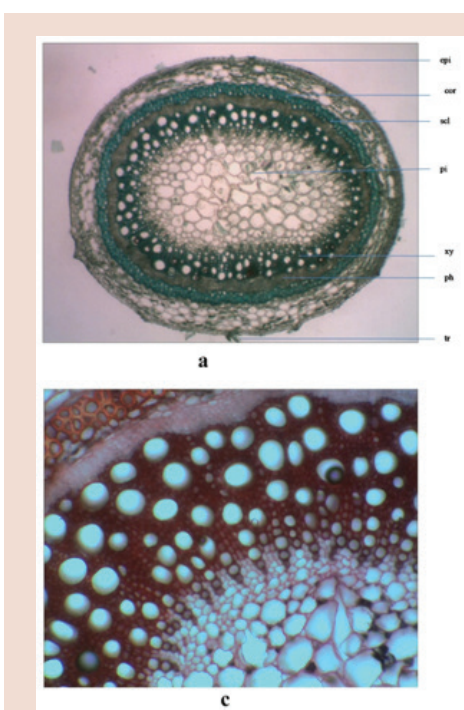

Figure 1: (a) T.S. of stem (4x); (b) Epidermis, cortex and sclerenchyma cells; (c) Vascular bundle and pith region; (d) Epidermis showing multi cellular trichome.

\section{Microscopical characters of Leaf}

T.S of the leaf passing through midrib region was convex at the lower side and grooved at the upper side, the young leaf showed the presence of the vascular bundle in the centre encircled by the parenchymatous cells. The upper epidermis and lower epidermis shows Anomocytic type of stomata and were made up of rectangular cells covered by thin cuticle, followed by this, on both regions 4-5 layers of thin walled, compactly 
arranged, rounded parenchymatous cells were present. Some of the cells of epidermis were elongated to form uni to multi cellular trichomes. In mature leaf, 4-5 layered parenchyma cells in the narrow groove at the upper side and 5 to 6 rows at the lower side was present. These parenchymatous cells were thin walled, compactly arranged without any air spaces. Most of the cells are filled with abundant starch grains with clustered calcium oxalate crystals. In the central region vascular bundles were arranged with an arc shaped, with well developed xylem and phloem cells. Transverse section of the leaf through laminar region showed well developed upper and lower epidermis covered with thin cuticle. The laminar mesophyll region shows two layers of compactly arranged palisade parenchyma cells, three to four layers loosely arranged spongy parenchyma cells. The crystals of calcium oxalate present abundantly in the upper portion of palisade parenchyma cells and very few in spongy parenchyma cells and few prism shaped crystals were present in the spongy parenchyma cells, both palisade and spongy parenchyma cells were filled with abundant, simple and compound starch grains in groups.

\section{Powder microscopy}

The whole plant powder was light green in colour. Smell not agreeable, bitter in taste and mucilaginous. Powder microscopy revealed the fragments of different tissues of epidermal cells, which were polygonal and tangentially elongated, thin walled parenchymatous cells, both the epidermis showed Anomocytic type of stomata, parenchyma cells with single layer of epidermis, multi cellular trichome, group of parenchyma cells, pollen grains, fibers in groups, reticulate and thickened helical vessels in groups, clustered calcium oxalate crystals (Figure 2).
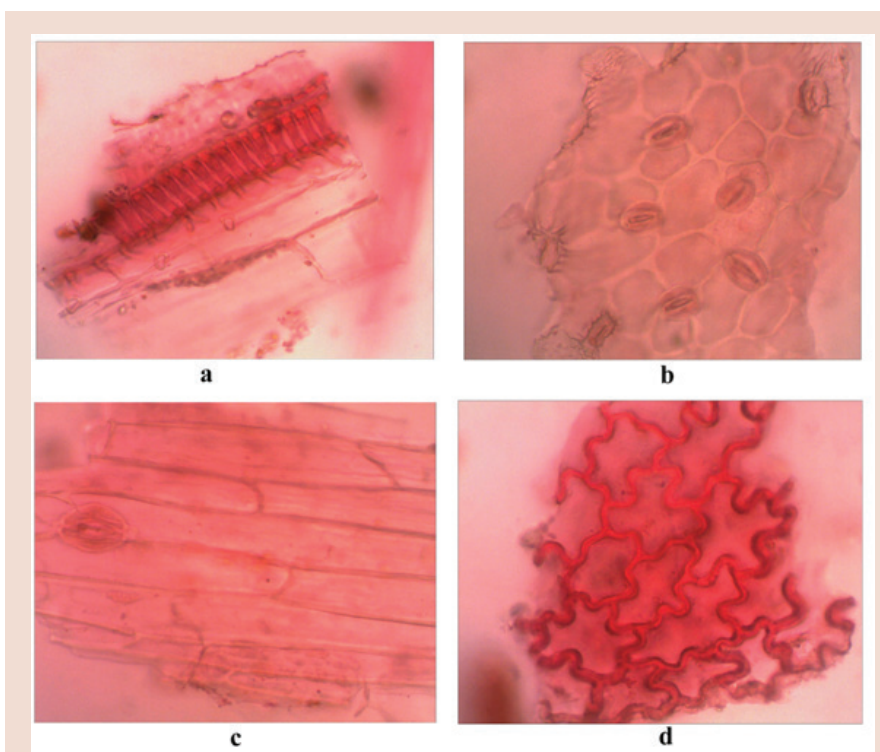

Figure 2: Powder microscopy of stem and leaf of Glinus oppositifolius (L.) Aug. DC. (a) Helical vessel (b) Stomata upper surface view (c) Upper Epidermal cells with stomata in surface view (d) Lower Epidermal cells in surface view

\section{Histochemical analysis}

\section{Stem}

Histochemical analyses were carried out on stem of Glinus oppositifolius (L.) Aug. DC. by using different chemical reagents and stains as per the standard procedures. It showed the presence of calcium, calcium pectate, silica, starch, magnesium, protein, poly phenols, phenols, sulphated muco polysaccharides, Lignin contents, Tannin contents in different tissues of the stem (Figure 3 and Table 1).

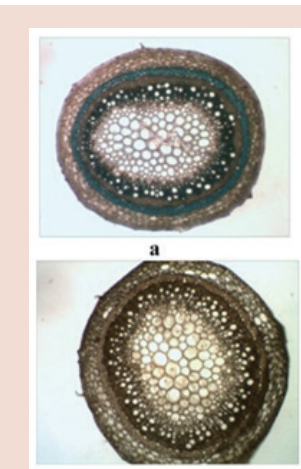

d

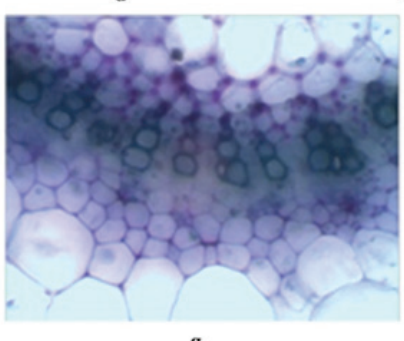

g

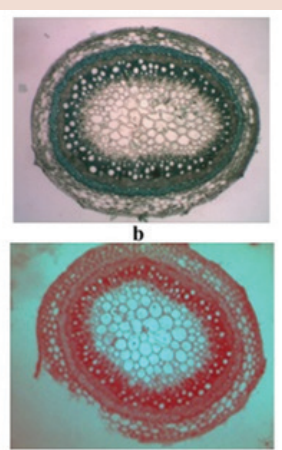

e

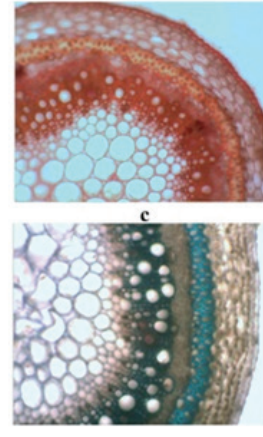

f

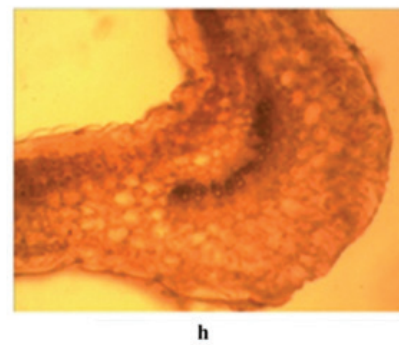

Figure 3: Histochemical analysis of leaf and stem of Glinus oppositifolius (L.) Aug. DC. (a) Protein content (stem) (4x); (b) Phenol content (stem) (4x); (c) Magnesium content (stem) (10x); (d) Calcium Pectate content (stem) (4x); (e) Silica content (stem) (4x); (f) Phenol content (stem) (10x); (g) Phenol content (leaf) (40x); (h) Calcium contents (leaf) (10x)

Table 1: Histochemical test of Glinus oppositifolius L.A. DC.

\begin{tabular}{|c|c|c|c|}
\hline S. No. & Histochemical & $\begin{array}{l}\text { Locality of the cells in } \\
\text { stem }\end{array}$ & $\begin{array}{l}\text { Locality of the cells } \\
\text { in leaf }\end{array}$ \\
\hline 1 & Phenols & $\begin{array}{l}\text { Sclerenchyma cells, } \\
\text { xylem cells, ray cells. }\end{array}$ & Xylem cells. \\
\hline 2 & Protein & $\begin{array}{l}\text { Sclerenchyma cells, } \\
\text { xylem cells, ray cells }\end{array}$ & $\begin{array}{l}\text { Xylem cells, starch } \\
\text { grains in the } \\
\text { parenchyma cells. }\end{array}$ \\
\hline 3 & Calcium & $\begin{array}{l}\text { Epidermis, starch grains, } \\
\text { cortical parenchyma } \\
\text { cells, sclerenchyma cells, } \\
\text { xylem cells. }\end{array}$ & All parts of the leaf. \\
\hline 4 & Magnesium & $\begin{array}{l}\text { Cutin layer, epidermis, } \\
\text { sclerenchyma cells, } \\
\text { vascular bundles. }\end{array}$ & Vascular bundles. \\
\hline 5 & Silica & Xylem cells and ray cells. & Xylem cells. \\
\hline 6 & Starch & $\begin{array}{l}\text { Starch grains in the } \\
\text { cortex region \& xylem } \\
\text { cells. }\end{array}$ & $\begin{array}{c}\text { Starch grains in the } \\
\text { parenchyma cells \& } \\
\text { xylem cells. }\end{array}$ \\
\hline 7 & Calcium pectate & $\begin{array}{l}\text { Epidermal cells, starch } \\
\text { grains, vascular bundles. }\end{array}$ & All parts of the leaf \\
\hline 8 & Lignin & $\begin{array}{l}\text { Sclerenchyma cells, } \\
\text { xylem cells, ray cells. }\end{array}$ & - \\
\hline 9 & $\begin{array}{l}\text { Sulphated muco } \\
\text { polysaccharides }\end{array}$ & $\begin{array}{l}\text { Sclerenchyma cells, } \\
\text { xylem cells, ray cells. }\end{array}$ & Xylem cells. \\
\hline
\end{tabular}

Histochemical Tests of Leaf

Histochemical analysis on leaf has been carried out by using different chemical reagents and stains according to standard procedures. These studies showed the presence of calcium, calcium oxalate, calcium pectate, silica, starch, magnesium, protein, poly phenols, phenols, sulphated muco polysaccharides, tannin contents in different tissues of the leaf (Figure 3 and Table 1). 


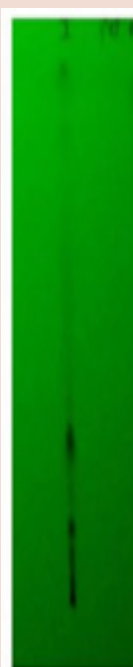

I

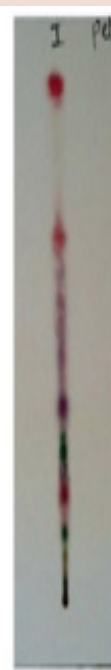

2

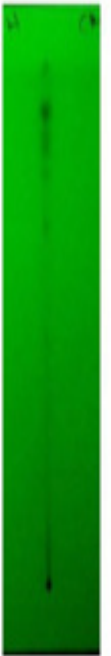

3

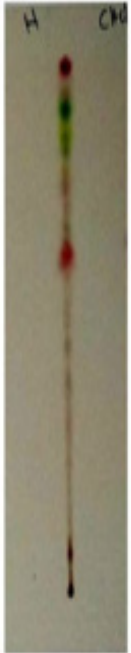

4

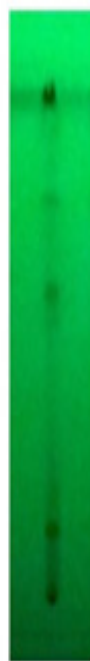

5

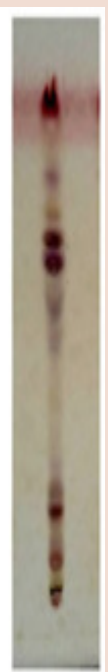

6
Figure 4: TLC Fingerprinting of Glinus oppositifolius (L.) Aug. DC. (whole plant)- 1-2 Petroleum ether extract; 3-4 Chloroform extract and 5-6 Methanol extract

\section{Micrometric Details}

Micrometric details of Glinus oppositifolius (L.) Aug. DC. stem and leaves were studied as per the standard procedures and recorded the measurements with the help of cat cam software (Table 2).

\section{Table 2: Micrometric details of stem}

\begin{tabular}{|c|c|c|c|c|c|}
\hline S. No & $\begin{array}{c}\text { Type of } \\
\text { Cell }\end{array}$ & $\begin{array}{c}\text { Minimum } \\
\text { Measurements } \\
\text { in } \mu \mathrm{m}\end{array}$ & $\begin{array}{l}\text { Maximum } \\
\text { Measurements } \\
\text { in } \mu \mathrm{m}\end{array}$ & $\begin{array}{l}\text { Average with } \\
\text { standard Error } \\
\text { Measurements } \\
\text { in } \mu \mathrm{m}\end{array}$ & $\begin{array}{c}\text { Stadandard } \\
\text { deviation in } \\
\mu \mathrm{m}\end{array}$ \\
\hline 1 & $\begin{array}{l}\text { Epidermal cell } \\
\text { width }\end{array}$ & 28.18 & 55.36 & 41.79 & 6.75 \\
\hline 2 & $\begin{array}{l}\text { Cortical } \\
\text { parenchyma } \\
\text { cells width }\end{array}$ & 28.64 & 149.83 & 85.18 & 26.87 \\
\hline 3 & Pith cell width & 77.1 & 216.07 & 131.30 & 38.99 \\
\hline 4 & $\begin{array}{c}\text { Xylem cells } \\
\text { width }\end{array}$ & 16.4 & 116.1 & 61.65 & 28.92 \\
\hline \multicolumn{6}{|c|}{ Micrometric details of Leaf } \\
\hline 5 & $\begin{array}{l}\text { Epidermal cell } \\
\text { width }\end{array}$ & 19.24 & 101.2 & 54.49 & 21.93 \\
\hline 6 & $\begin{array}{l}\text { Midrib } \\
\text { parenchyma } \\
\text { cells width }\end{array}$ & 155.72 & 155.72 & 64.67 & 24.48 \\
\hline 7 & $\begin{array}{l}\text { Palisade } \\
\text { parenchyma } \\
\text { cells width }\end{array}$ & 58.52 & 91.27 & 72.01 & 9.24 \\
\hline 8 & $\begin{array}{l}\text { Spongy } \\
\text { parenchyma } \\
\text { cells width }\end{array}$ & 40.31 & 107.3 & 63.03 & 14.22 \\
\hline 9 & $\begin{array}{c}\text { Xylem cells } \\
\text { width }\end{array}$ & 38.08 & 85.02 & 65.38 & 12.24 \\
\hline 10 & $\begin{array}{l}\text { Epidermal cell } \\
\text { width }\end{array}$ & 19.24 & 101.2 & 54.49 & 21.93 \\
\hline 11 & $\begin{array}{l}\text { Midrib } \\
\text { parenchyma } \\
\text { cells width }\end{array}$ & 155.72 & 155.72 & 64.67 & 24.48 \\
\hline
\end{tabular}

\section{Quantitative study of Leaf}

Quantitative study of leaf has been carried out according to standard procedures with the help of cat cam software and the measurements were recorded (Table 3 ).

Table 3: Quantitative study of leaf Glinus oppositifolius L.A. DC

\begin{tabular}{ccc}
\hline S.No. & Details & Result \\
\hline $\mathbf{1}$ & Stomatal ratio lower epidermis & $8-13-18$ / sq.mm \\
$\mathbf{2}$ & Stomatal ratio upper epidermis & $3-6-9$ / sq .mm \\
$\mathbf{3}$ & Stomatal index lower & $8.22-13.36-20.45 /$ sq.mm \\
$\mathbf{4}$ & Stomatal index upper & $2.25-4.54-6.25 /$ sq.mm \\
$\mathbf{5}$ & Palisade ratio & $8-11-13-/$ sq.mm \\
$\mathbf{6}$ & Vein islet numbers & $4-8-10 /$ sq.mm \\
\hline
\end{tabular}

\section{Physico-chemical analysis}

Physico-chemical analysis of the whole plant powder of Glinus oppositifolius (L.) Aug. DC. revealed loss on drying $6.09 \% \mathrm{w} / \mathrm{w}$, total ash content $11.30 \% \mathrm{w} / \mathrm{w}$, acid-insoluble ash content $1.02 \% \mathrm{w} / \mathrm{w}, \mathrm{pH}$ of $5 \%$ aqueous solution 6.95 , water soluble extractive $25.07 \% \mathrm{w} / \mathrm{w}$, alcohol soluble extractive $10.67 \% \mathrm{w} / \mathrm{w}$ were carried out as per the standard procedures (Table 4 ).

\section{Table 4: Physico-chemical parameters}

\begin{tabular}{ccc}
\hline S. No. & Name of the parameter & Values (\%) w/w \\
\hline $\mathbf{1}$ & Description & Light green coarse powder \\
$\mathbf{2}$ & Foreign matter & Less than $2.0 \%$ \\
$\mathbf{3}$ & $\mathrm{pH}(10 \%$ w/v aq. solution) & 6.95 \\
$\mathbf{4}$ & Loss on drying at 1050C & 6.09 \\
$\mathbf{5}$ & Total ash & 11.30 \\
$\mathbf{6}$ & Acid-insoluble ash & 1.02 \\
$\mathbf{7}$ & Water-soluble extractive & 25.07 \\
$\mathbf{8}$ & Alcohol-soluble extractive & 10.67 \\
$\mathbf{9}$ & Petroleum ether soluble extractive & 1.17 \\
$\mathbf{1 0}$ & Chloroform soluble extractive & 0.80 \\
\hline
\end{tabular}

\section{Preliminary phytochemical analysis}

Preliminary phytochemical screening of the whole plant powder of Glinus oppositifolius (L.) Aug. DC. showed the presence of secondary metabolites like alkaloids, carbohydrates, proteins, phenols, saponins, steroids and tannins (Table 5).

\section{Thin Layer Chromatography (TLC) fingerprinting studies}

TLC studies were performed for the development of characteristic fingerprint profile for different extracts. The powdered drug ( $2 \mathrm{~g}$ in 25 $\mathrm{ml}$ ) has been extracted with different solvents like petroleum ether, chloroform and methanol at room temperature further used to establish the TLC fingerprints by using different solvent systems on trial and error basis such as Toluene: Hexane: Ethyl acetate-6:3.5:0.5 for Petroleum ether extracts (PE), Toluene: Ethyl acetate: Chloroform-6:3.5:0.5 for Chloroform extracts and Ethyl acetate: Methanol: Ethanol: Water-8.1: 1.1: 0.4: 0.8 for Methanol extracts of the whole plants, the plates were dried at room temperature for 5-10 minutes and observed under UV-254 nm and sprayed with Anisaldehyde- $\mathrm{H}_{2} \mathrm{SO}_{4}$ reagent and $\mathrm{R}_{\mathrm{f}}$ values were recorded. In the petroleum ether extract 6 spots were visualized at $0.125,0.21,0.30,0.375$, $0.575,0.725$, chloroform extract exhibited 8 spots with $\mathrm{R}_{\mathrm{f}}$ values 0.41 , $0.49,0.65,0.70,0.79,0.84,0.89,0.925$. Methanol extract showed a total of eleven spots $0.14,0.725,0.79,0.19,0.22,0.51,0.575,0.66,0.70,0.75,0.825$ before and after derivetization (Figure 4). TLC analysis is an important tool for quality evaluation and standardization of the crude drug. This TLC fingerprint profile carried out may be used as standard to identify the plant drug and to detect the adulteration by observing the number of spots and $\mathrm{R}_{\mathrm{f}}$ values for particular extract with respect to its mobile phase. 
SHANTHA T R et al.: Pharmacognostical Evaluation of Glinus oppositifolius (L.) Aug. DC.

Table 5: Preliminary Phytochemical tests for different extracts of Glinus oppositifolius L.A. DC (Whole plant).

\begin{tabular}{|c|c|c|c|}
\hline S. No. & Phytoconstituents & Test performed & Inference \\
\hline \multirow{4}{*}{1} & \multirow{4}{*}{ Alkaloids } & (a) Dragendorff's test & +++ \\
\hline & & (b) Hager's test & +++ \\
\hline & & (c) Mayers's test & +++ \\
\hline & & (d) Wagner's test & +++ \\
\hline \multirow{4}{*}{2} & \multirow{4}{*}{ Carbohydrates } & (a)Anthrone test & +++ \\
\hline & & (b) Benedict's test & +++ \\
\hline & & (c) Fehling's test & +++ \\
\hline & & (d) Molisch's test & +++ \\
\hline 3 & Flavonoids & -- & -- \\
\hline \multirow{2}{*}{4} & \multirow{2}{*}{ Phenols } & (a) Ferric chloride test & +++ \\
\hline & & (b) Lead acetate test & +++ \\
\hline \multirow{2}{*}{5} & \multirow{2}{*}{ Proteins } & (c) Biuret's test & +++ \\
\hline & & (d) Millon's test & +++ \\
\hline 6 & Saponins & -- & +++ \\
\hline 7 & Starch & -- & - \\
\hline 8 & Steroids & Salkowski reaction & +++ \\
\hline \multirow{2}{*}{9} & \multirow{2}{*}{ Tannins } & (a) Ferric chloride test & +++ \\
\hline & & (b) Lead acetate test & +++ \\
\hline 10 & Resins & & - \\
\hline
\end{tabular}

+++ Presence of the Phytochemical, --- Absence of the Phytochemical.

\section{Nutritional evaluation}

Nutritional analysis was carried out for proteins, carbohydrates, vitamin C, calcium, Iron, zinc, vitamin B1, B2, B3, fat, calories, crude fiber, moisture, minerals. The leaf of Glinus oppositifolius (L.) Aug. DC. can be used as a remedy, which is enriched with essential dietary supplements, nutrients, and phytochemicals and got potentiality to fight against Diabetes, in controlling the sugar level as well in balancing level of insulin in the human body. The nutritional benefits are proven from the present study where it is clearly evident that the plant is rich in the macro elements such as Calcium which is essential for nerve impulse conduction and activates some enzymes, which generates neurotransmitters and plays an important role in building strong, dense and healthy bones and teeths; Zinc which is essential for different enzyme systems in the body as cofactor, these enzyme systems are responsible for every major physiological function that necessitates catalytic activity from enzyme at the molecular level, ${ }^{26}$ the plant also showed the presence of Iron which is the basic element in the formation of haemoglobin and other important vitamins as vitamin C (Table 6).

\section{ACKNOWLEDGEMENT}

This study was fully funded under Intra Mural Research Project policy of CCRAS, Authors are thankful to the DG, CCRAS and Ministry of AYUSH, for funding and to carry out the project successfully and Dr. V. Rama Rao, Research officer (Botany), NADRI-Bangalore for procuring and authenticating the drug.

\section{ABBREVIATION USED}

epi-epidermis, cor-cortex, scl-sclerenchyma, ph-phloem; pi-pith, tr-trichome, $x y$-xylem.

\section{Table 6: Nutritional values of the whole plant}

\begin{tabular}{ccc}
\hline S. No. & Parameters & Results \\
\hline $\mathbf{1}$ & Fat & $2.3 \%$ by wt \\
$\mathbf{2}$ & Crude fibre & $22.4 \%$ by wt \\
$\mathbf{3}$ & Protein & $12.5 \%$ by wt \\
$\mathbf{4}$ & Carbohydrates by difference & $47.0 \%$ by wt $)$ \\
$\mathbf{5}$ & Calorific value & $245 \mathrm{kcal} / 100 \mathrm{~g}$ \\
$\mathbf{6}$ & Vitamin C & $112 \mathrm{mg} / 100 \mathrm{~g}$ \\
$\mathbf{7}$ & Calcium & $1693 \mathrm{mg} / 100 \mathrm{~g}$ \\
$\mathbf{8}$ & Iron & $22.1 \mathrm{mg} / 100 \mathrm{~g}$ \\
$\mathbf{9}$ & Zinc & $43.2 \mathrm{mg} / 100 \mathrm{~g}$ \\
$\mathbf{1 0}$ & Vitamin B1 & Below detection level of 0.05 \\
$\mathbf{1 1}$ & Vitamin B2 & Below detection level of 0.05 \\
$\mathbf{1 2}$ & Vitamin B3 & $0.1 \mathrm{mg} / 100 \mathrm{~g}$ \\
\hline
\end{tabular}

\section{REFERENCES}

1. Proshanta M, Harisha CR, Shukla VJ. A Comparative pharmacognostical and phytochemical study on different plant sources of Parpatak. World Journal of Pharmaceutical Research 2014; 3(4): 1531-48.

2. Chunekar KC, Bhavprakash Nighantu. Chaukhambha Bharti Academy. Varanasi, $7^{\text {th }}$ Ed; 1986. 323-8.

3. Anonymous, The Ayurvedic Pharmacopoeia of India. CCRAS, Part-1, Vol. IV. Department of AYUSH, M/o Health and Family Welfare, Government of India; 2004. 84-6.

4. Anonymous. Wealth of India, Raw Materials. Vol. IV, Publications and Information Directorate, CSIR, New Delhi; 1956. p. 136.

5. Asokkumar K, Umamaheswari M, Sivashanmugam AT, Subhadradevi V, Subhashini N, Ravi TK. Free radical scavenging and antioxidant activities of Glinus oppositifolius (carpet weed) using different in vitro assay systems. Pharmaceutical Biology 2009; 47(6): 474-82.

6. Diallo D, Marston A, Terreaux C, Toure Y, Smestad Paulsen B, Hostettmann K. Screening of Malian medicinal plants for antifungal, larvicidal, molluscicidal, antioxidant and radical scavenging activities. Phytotherapy Research 2001; 15(5): 401-6.

7. Dutta B, Mitalighosal, Chakrabarty B, Palashmandal. Anthelmintic and free-radical scavenging potential of various fractions obtained from foliar parts of Glinus oppositifolius (Linn.) DC. International Journal of Pharmacy and Pharmaceutical Sciences 2012; 4(4): 233-9.

8. Gopinathan S, Nija S. Gastric ulcer curative potential of Mollugo oppositifolia L. extract- a preclinical study. World Journal of Pharmaceutical Research 2014; 3(7): 929-48.

9. Gupta M, Mazumder UK, Haldar PK, Manikandan L, Senthilkumar GP, Kandar CC. Hepatoprotective activity of methanol extracts of Glinus oppositifolius and Trianthema decandra against paracetamol induced liver damage. Oriental Pharmacy and Experimental Medicine 2007; 7(1): 74-8.

10. Sahu SK, Das D, Tripathy NK. Hepatoprotective activity of aerial part of Glinus oppositifolius L. against Paracetamol-induced Hepatic Injury in Rats. Asian J. Pharm. Tech. 2012; 2(4): 154-6.

11. Nazia $H$, Razibulhabib M, Zafar Imam M, Jamiuddin A, Sohelrana M. Analgesic and anti-inflammatory potential of methanolic extract of Glinus oppositifolius L. Australian Journal of basic and applied sciences 2011; 5(8): 729-33.

12. Nazia Hoque, Zafar mam M, Saleha $A$, Hoquemazumder ME, Raquibulhasan SM, Jamiuddin A, et al. Antioxidant and antihyperglycemic activities of methanolic extract of Glinus oppositifolius leaves. Journal of applied pharmaceutical science 2011; 1(7): 50-3.

13. Sahu SK, Das D, Tripathy NK, Dinda SC, Sundeepkumar HK. Evaluation of hypoglycemic activity of Mollugo pentaphylla and Glinus oppositifolius L. Asian J. Chem. 2012; 5(1): 57-62.

14. Siromoney G, Giles LD, Livingstone C. Herbal medicines of the Narikoravas. Folklore. 1973; 14(10): 363-6.

15. Khare CP. Indian Medicinal plants. An Illustrated dictionary. Berlin/ Heidenberg: springer; 2007. 421.

16. Kirtikar KR, Basu BS. Indian Medicinal Plants. Bishensingh Mahendra Pal Singh, Dehradun. II; 1993. 1184-5.

17. Dongarwar N, Uma thakur, Dongarwar S, Wadekar M. Ethnomedicines among some tribes of Nandurbar district of M.S. (India). Life sciences Leaflets 2012; 4(1): 48-53.

18. Thirunarayanan T. Ethnobotanical survey on folk Medicine in the management of animal bite poisons in the forest tract of Salem region of Tamil Nadu, India. International Journal of Pharmacology and Clinical Sciences 2013; 2(2): 41-6. 
19. Evans WC, Trease D. Pharmacognosy. Edinburgh Saunders Company; 2002. p. $519-20$.

20. Wallis TE. Text book of Pharmacognosy. New Delhi CBS Publishers and Distributors; 1985. p. 572-5.

21. Krishanmurthy KV. Methods in Plant Histo-chemistry. Madras: S. Vishwanathan Printers and Publishers Private Limited; 1988. 1-64.

22. Anonymous, The Ayurvedic Pharmacopoeia of India. Part-II, Vol. III.CCRAS, Department of AYUSH, M/o Health and Family Welfare, Government of India; 2010.

23. Anonymous Physico-chemical standards of Unani formulations. Part-IV Central Council for research in Unani Medicine (CCRUM), Dept. of AYUSH, M/o Health and Family Welfare, Govt. of India, New Delhi; 2006. p. 157-60.

24. Sethi PD. HPTLC High Performance Thin Layer Chromatography-Ouantitative Analysis of Pharmaceutical Formulations. CBS Publishers and Distributors, New Delhi, India; 1996. p. 3-68.

25. George LatimerW, (Editor). Chapter 45. Association of Official Analytical Chemists (AOAC) International. 19 ${ }^{\text {th }}$ Edition, Roickville, USA; 2012, 1-86.

26. Tewari D, Pandey HK, Sah AN, Meena HS, Manchanda A. Pharmacognostical and biochemical investigation of Ocimum kilimandscharicum plants available in western Himalayan region. Asian Journal of Plant Science and Research 2012; 2(4): 446-51.

\section{PICTORIAL ABSTRACT}

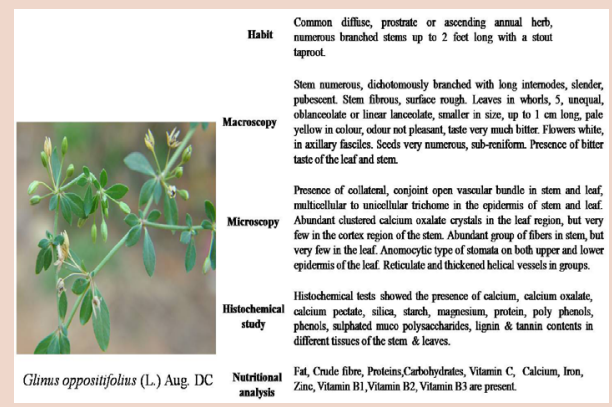

\section{SUMMARY}

- The present study is an effort in the path of several standardization parameters. Studies revealed the presence of different phytochemicals with versatile uses which helps for different diseases apart from diabetes.

- Presence of poly phenols and polyphenolic compounds may be useful for the prevention of diabetic complications including cardiovascular diseases, neuropathy, nephropathy and retinopathy etc.

- The different parameters studied also help in establishing Pharmacopoeial standards which are urgently required not only for the survival of the age old traditional systems of medicine but also in the view of the fact that these systems are attaining global importance.

- The nutritional values of the plant also suggested the economical benefits and the importance of the plant as a dietary supplement. Good nutritional and calorific value, vitamin $\mathrm{C}$ content and higher amount of calcium suggested the importance plant as a dietary supplement.

- All these results presented in this study may be strongly proposed as parameters to establish the authenticity and to differentiate the drug from other species and also serves as standard parameters in order to check the purity, quality and to avoid the adulteration.

\section{ABOUT AUTHOR}

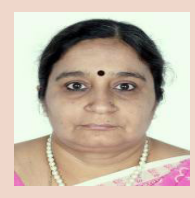

Dr. ShanthaT R: Is working as Research officer (Botany) in Central Council for Research in Ayurvedic Sciences, Ministry of AYUSH, Govt. of India. She has experience in the area of Pharmacognosy since 33 years. She has published more than 70 Research papers in National \& International peer reviewed Journals and carried out pharmacognostical studies on more than 250 medicinal plant drugs. She has obtained her Ph.D degree in the year 1996 from University of Mysore, on Macro, microscopic and preliminary phytochemical studies on the different botanical sources of Pashanabheda-a controversial Ayurvedic drug. She is a recognised guide for Ph.D, under University of Mysore, Mysore. 